\title{
The Quality of Islamic Religious Colleges: Ideal Format and Reality Conditions and Affecting Factors
}

\author{
A. Suradi \\ Tarbiyah and Tadris Faculty of IAIN Bengkulu Indonesia \\ Email: suradi@iainbengkulu.ac.id \\ Nilawati \\ Nurul Huda Foundation of Bengkulu \\ Email: nilawati@nurulhudafoundation.id \\ Received: March 22, 2021 | Accepted: June 22, 2021
}

\begin{abstract}
This article describes how the quality of Islamic religious colleges and what factors influence them. The ideal format of Islamic religious colleges in achieving quality is the wider concept of science in the Islamic view; conceptualization; the existence of an academic community that has a soul of devotion, discipline, and critical understanding; selection of students as supporting the achievement of quality improvement; as well as academic traditions. In reality, the quality of Islamic religious college as a potential resource is still far from expectations. This happens, in addition to the low quality of education in Islamic religious colleges, also caused by the lack of effort and efforts of academic civitas reach toward quality. Thus, describing the conditions among them is the low education service and the low literacy ability of Islamic religious college students. Practically this reality shows that education in Islamic religious colleges today is experiencing many challenges and problems. Automatically these conditions have a direct impact with the resulting output. Due to the low quality of Islamic religious college education, the resulting low quality of graduates.
\end{abstract}

\begin{abstract}
Abstrak
Artikel ini mengelaborasi ide tentang bagaimana kualitas perguruan tinggi agama Islam dan faktor-faktor apa saja yang mempengaruhinya. Format ideal perguruan tinggi agama Islam dalam mencapai mutu adalah konsep keilmuan yang sejatinya lebih luas dalam pandangan Islam. Secara konseptual, kualitas pendidikan tinggi antara lain ditentukan oleh adanya civitas akademika yang memiliki jiwa pengabdian, disiplin, dan pemahaman kritis, seleksi mahasiswa sebagai penunjang pencapaian peningkatan kualitas, serta tradisi akademik yang mumpuni. Namun, pada kenyataannya kualitas perguruan tinggi agama Islam sebagai sumber daya yang potensial
\end{abstract}


masih jauh dari harapan. Hal ini terjadi, selain rendahnya mutu pendidikan di perguruan tinggi agama Islam, juga disebabkan oleh kurangnya upaya sivitas akademika untuk mencapai mutu. Selain itu, rendahnya layanan pendidikan dan rendahnya kemampuan literasi mahasiswa perguruan tinggi agama Islam adalah factor-faktor yang berkontribusi pada problem mutu pendidikan tinggi Islam. Secara empiric, perguruan tinggi agama Islam dewasa ini mengalami banyak tantangan dan permasalahan yang kemudian berdampak langsung dengan output yang dihasilkan, karena rendahnya kualitas pendidikan perguruan tinggi agama Islam berakibat pada rendahnya kualitas lulusan.

\section{Keywords}

The Quality, Islamic Religious, Colleges

\section{Introduction}

The quality of a qualified Islamic college can only be realized with a quality educational process. Quality education process is a system that is able to develop the positive potentials buried in students. With the system of quality education in Islamic religious colleges, will produce potential young workers are tough and ready to compete in the world community. Therefore, efforts to improve the quality of Islamic religious colleges is something that can not be negotiable in order to improve the quality of Indonesian nation's resources. Quality education system is a systematic process to improve human dignity holistically.

Initially, the establishment of the State Islamic Religious College was only intended as a continuation of the government's program of "modernizing" traditional Islamic education and preparing staff to fill religious duties. However, now the goal has undergone a shift and extension of the mission, in line with the development of Islamic religious colleges themselves in answering the demands of the times. Nevertheless, it seems that the institutional development has not fully guaranteed the existence of the higher education institution to become a place of learning with the title of "academic excellence." Therefore, in order to achieve the ideals as expected, then every Islamic religious college must dare to take the policy whose orientation and orientation is more focused on academic missions. In this way it is expected to improve the quality of Islamic religious college equivalent and class with other public universities, without leaving the uniqueness of the field of study about the Islam in it.

In the early decades of its development, Islamic studies in Islamic religious colleges as described by Azra (2005, p. 25) have four main trends; first, normative-idealistic; secondly, the orientation of the sectarianism of the school, especially the Shafii school of jurisprudence and the flow of kalam 
Asy'ari; third, the direction of science to the Middle East; and fourth, isolated from the broader scientific discourses. In this phase, it seems that epistemologically, the tradition of Islamic Studies in Islamic religious colleges is not much different, not to say exactly the same, from Islamic studies in pesantren. Islamic religious colleges as elements of the National Education System should not isolate themselves from new paradigm shifts, concepts, visions and orientations of higher education/national higher education, and even internationally. Because if not, the worst consequences that will be faced by Islamic religious colleges is social impact as a result of the failure of Islamic religious colleges in the face of modernization in the form of loss of trust from the community because it is not accommodative to change so that eroded the changing times.

According to Komaruddin Hidayat (2000), the function of Islamic religious college lies in the extent to which he can offer solutions to various problems of education in particular and the problems of mankind in general. Azyumardi Azra (2000) highlights more specifically on the Faculty of Tarbiyah. Faculty of Tarbiyah, according to him, both who are in Islamic religious colleges and others have stagnated. Husni Rahim (1998) explicitly said that if the Faculty Tarbiyah Islamic religious colleges do not want to think about madrassas and can not provide alternative solutions to the problems faced by madrasah, better dissolved only. From some of the above descriptions it seems once anxiety that academics see Islamic religious college as a very strategic institution is not able to do better in the development of science and civilization for mankind.

Like the facts in the field, the selection of the Candidates For Civil Servants (CPNS) 2017 acceptance of The State Islamic Institute of Bengkulu Lecturer formation, all applicants with The State Islamic Institute of Bengkulu graduates did not pass the test. Precisely who passed the Candidates For Civil Servants formation is a college graduate outside The State Islamic religious colleges. So, with this orientation of Islamic high education should be able to prepare learners to be proficient academic and professionals in practice, so as to compete with other universities.

In addition, in the assessment of this plural society, The State Islamic religious colleges out-puts are faced with diverse demands. In this case polarized to two groups of society, namely: first, students and graduates of The State Islamic religious colleges generally do not have adequate knowledge or otherwise not very weak in their mastery of classical texts, compared to those with pesantren background. Though the main literature that must be studied in The State Islamic religious colleges derived from the classic text itself. Second, students and alumni of The State Islamic religious colleges generally tend to think normatively, they are less able to understand the context and the empirical substance of the religious issues. With its weakness capturing the aspect of empiricism from 
various religious problems arising, this resulted in their lack of ability to propose realistic, problem-solving alternatives.

That indeed one of the expectations expected by the Indonesian Muslim community to The State Islamic religious colleges is to be able to become a forum for creating ulama and intellectuals in one individual body. However, these expectations seem unlikely to be realized given the many problems faced by The State Islamic religious colleges to date. These problems include the lack of scientific spirit among the educators in The State Islamic religious colleges which then penetrated to the students, weak mastery and the use of foreign languages especially Arabic and English, then the weak scientific methodology developed in The State Islamic religious colleges.

Associated with Islamic college today, the number of The State Islamic religious colleges from day to day in quantity experienced significant growth, even according to data Media Room Campus in 2018, 53 colleges (http://ruang-kampus.blogspot.co.id, 2018). Of course with the amount, in terms of quantity, it is worth to be grateful. However, it should be questioned how far the condition of some The State Islamic religious colleges. That is, how far the quality of The Islamic religious colleges compared with The Public Colleges? Whether they are truly colleges, or simply a "gift" institution, who never knows how the competence and acceptability of graduates in society, and what factors influence them. So in this case, will be discussed about the challenge of improving the quality of human resources in Islamic religious colleges.

\section{Ideal Concept Development of Islamic Religious Colleges}

In Indonesia, Islamic colleges as a whole can not be seen as an educational system that has the freedom to autonomously govern itself. As stated by Bilgrami and Ali Ashraf quoted by Madnasir, the formation of such Islamic colleges requires a long journey to correct the situation and develop a unified educational system for the Islamic world (Madnasir, 2016, p. 3).

In principle, Islamic religious colleges as institutions of higher education, legally-formal (see details of UU SISDIKNAS Number 20, Year 2003 Article 14), its existence is not different from other public universities, that is, the National has the same objectives regulated in Government Regulation no. 60 Year 1999, Article 2 paragraph (1) on Higher Education goal which reads:

1. Preparing learners to be members of the community who have academic and/or professional skills who can apply, develop and/or enrich the treasures of science, technology and/or art;

2. Develop and disseminate science, technology and/or art and strive for its use to improve people's lives and enrich national culture. 
Therefore, as part of the sub-system of National Education, Islamic religious colleges are also bound by the commitment to carry out the main mission of universities, namely Tri Dharma Colleges. In order to hold such a strong commitment, Islamic religious colleges color it with self-image that highlight the life of religious (Islamic) spirit. Commitment of Tri Dharma of Colleges above is presented in Government Regulation number 60 Year 1999 Article 3, on the Implementation of college which reads:

1. The college organizes higher education, research and community service.

2. Higher education is an activity in an effort to produce an educated human as referred to in Article 2 paragraph (1).

3. Research is an observation activity of rules in an attempt to discover the truth and/or solve problems in science, technology, and / or art.

4. Community service is an activity that utilizes science in an effort to contribute to the progress of society.

For that need to readiness of colleges with all the tools including the main one is the academic staff as the main driver of learning activities, so that lecturers must get career coaching that is planned and proportional. According Soedijarto (2008, p. 143), There are three factors that determine the process of success in a higher education; first, input factor (Raw Input); ie raw input in the form of students who process learning activities, secondly, environmental factors (Environmental Input); outside the campus environment or outside of the learning activities, such as: ecology, family, society; third, instrumental facto Input; tools of purpose, curriculum, media, including educators. These three factors will then undergo a process of educational transformation which then produces what is called an out-put or a graduate.

The above mentioned demands have also been affirmed in Government Regulation Number 19, Year 2005 on National Education Standards in Article 36 paragraph (1) that is, Education Personnel in higher education must possess qualification, competence and certification in accordance with their field of duty. Indirectly to get a better quality of education then the overall educational tools should be good also including academic staff.

Ideally, the educational component that needs to be developed in order to obtain the quality of education, includes several things: First, the college policy should show clear direction on the goals and targets to achieve and how to achieve them. Second, the development of the competence of teaching staff, as the leading motor in change must be the first party to be ready in this process of change. Third, Technology, technology integration in learning process is a necessity. Fourth, Research and evaluation, the educational process at universities requires feedback and research to improve the education system. Fifth, the curriculum, as the 
design of learning must be in line with the demands of the times (Widodo, 2015, p. 298).

With the format mentioned above, as a form of realizing Islamic universities as a vehicle that is expected to be able to develop knowledge and contribute to the improvement of a nation and state. So that Islamic universities are not only trying to produce good graduates, but also qualified, skilled and ready to work. Efforts to improve the quality of human resources in Islamic universities, prioritize discussing the relevance of education to development which in its implementation step is known as linkage and equivalence.

In addition, as revealed by Zainal Fitri (2013, p. 241), that qualified Islamic colleges should at least be able to meet the needs of stakeholders, in the form: (1) social needs (community needs); (2) industrial needs; and (3) professional needs. Therefore, only with in-depth knowledge of what these service and workplace users need, education will be able to achieve results that match their mission and vision.

Thus, for the achievement of this goal, the format that needs to be met in advance in achieving the quality of Islamic colleges, namely: First, the concept of knowledge in a broader perspective of Islam, as well as the existence of freedom college in the field of study that must be taught and its organization; Second, the conceptualization of Islamic religious colleges will not be realized simply because of money, buildings, or because there have been many scholars in various fields. So the main principle needed to achieve that goal is that Islamic religious colleges must be researchoriented from the outset; Third, the staff, that is required by the academic community that has the soul of devotion, diligence, discipline, breadth of view, and critical understanding; Fourth, the selection of students as a supporter to achieve quality improvement, hence required a more rigorous selection of students who will enter the Islamic religious college; Fifth, academic tradition, because in general it can be said that scientific mental attitude has not been formed in Islamic religious colleges, both among lecturers, especially among students. The atmosphere on campus until now is arguably not yet achieved the achievement of a qualified academic scholar. What is seen is the routine atmosphere of the academic community that organizes the educational process from day to day; Sixth, Islamization of science in relation to the characteristics of openness and freedom of Islamic religious colleges; Seventh, the existence of the core curriculum; Eighth, the existence of supporting institutions; and Ninth, education/training of teaching and learning for the development of teaching methodology.

With the format mentioned above, as a form of realizing the Islamic college as a vehicle that is expected to develop science and contribute to the improvement of a nation and state. So that Islamic 
colleges not only trying to produce good graduates, but also qualified, skilled and ready to work. Efforts to improve the quality of human resources in Islamic colleges, preferably discusses the relevance of education with development which in the implementation step is known by the relationship and correspondence.

\section{Portrait of Reality and Factors Affecting the Quality of Islamic Religious College}

Improved economic and welfare levels of the community cause the community to demand improved quality of life, including in the field of education. The public wants the provision of quality education. While Islamic religious colleges are considered second-class colleges. Thus, not a few number of graduate of Islamic religious colleges are considered less skilled in carrying out the service function to the people, especially leading various religious ritual events, such as tahlil, talqin, marhaban and others. Thus, the graduate of Islamic religious colleges in addition to having adequate intellectual ability, they are also required to have the practical ability to perform religious ritual functions for the Muslim community widely. Because, in view of the general public, Islamic religious colleges are educational institutions for the cadre of prospective scholars. Therefore, the demands of such society must, however, be accommodated. The more so in reality, most of the graduate of Islamic religious colleges in time will return to the society still need the guidance of religious rituals.

As a result, many graduates of Islamic religious colleges are unemployed. This was conveyed by A. Chotib Qudwain, former Rector of The State Islamic Institute of Sultan Thoha Jambi. According to him, he felt the laughter of The State Islamic Institute graduate when looking at their faces, as if The State Islamic Institute graduate regretted having studied in a place with limited access to the world of work (Arifah, 2017, p. 30). Further implication is the birth of students' attitudes and attitude toward religion in relation to the challenges of modernization tend to be very narrow, or legalistic and formalistic. On this basis, it requires empirical insight other than the mastery of classical texts. For that contact cooperation and consultation with non-religious colleges can not be avoided.

The other deficiencies side of the Islamic religious college are; first, his weakness in developing new knowledge. This condition is in stark contrast with the current world situation, that is the explosion of knowledge influence on the patterns of global association. In general, nations or groups capable of generating new knowledge will be able to seize a favorable place in their interactions with other nations or groups. The facts show that the dominance of Western culture or developed countries over other cultures in the world is basically due to the nation's 
ability to develop new knowledge, new information, new technologies and new cultures.

Second, Islamic religious colleges, graduates have not understood the source of Islamic teachings (Al-Qur'an an Hadith); the ability of language graduates of Islamic religious colleges is still low, especially Arabic and English; graduates of Islamic religious colleges are still lacking in oral and written communication; Islamic religious college graduates still face difficulties in seizing available employment; graduates of Islamic religious colleges are still dependent on others, and still low in mastering the science that interest it.

The condition is influenced by several factors, namely 1) the teaching is still the formality and theoretical nature of the lectures and examinations; 2) lack of training and academic activities; 3) the relationship of lecturers and students who are still formal and learning processes are still like in school; 4) the lack of research conducted by lecturers; 5) awareness and motivation of students to master the language and knowledge that qualified is still lacking, still oriented to degree and diploma.

On the other hand, the low quality of Islamic religious colleges can be seen from three elements, namely lecturers, students and administrative staff. First, the lecturers of Islamic religious colleges have the status of civil servants, affect their work motivation, in addition to the lecturers with the status of civil servants (extraordinary lecturers) insufficient insufficient, so that the schools are limited to perform teaching tasks and assess the work of students. So that happened between the lecturer and the student is still transactional. Lecturers who have autonomy are not balanced with effective supervision, in addition to the lack of competition and selection of lecturers achievers make lecturers quickly satisfied with minimal achievement

Secondly, students are less likely to have quality achievement targets; student activities are still limited to regular lectures (lectures, exams, graduation and graduation); no competition to develop achievements; still lack of awareness of the demands of the future profession; and still many students believe the diploma is the provision of life. Thirdly, aspects of administrative personnel, Islamic religious colleges still reveal bureaucratic, rigid and formal conditions; waiting atmosphere for instructions (implementation guidance and technical guidance); routine and consequently is boring; as well as less to show the nature of excellent service and less friendly to students.

The number of conditions in the field described above, indicates that the quality of Islamic religious college as a potential resource is still far from expectations. This happens, in addition to the low quality of education in Islamic religious colleges, also caused by the lack of effort and 
efforts to achieve the quality. Thus, Islamic religious colleges describe conditions such as the low level of education services in Islamic religious colleges, the low quality of education in Islamic religious colleges, the low literacy ability of Islamic religious college students. Practically this reality shows that education in Islamic religious colleges today is experiencing many challenges and problems. Automatically these conditions have a direct impact with the resulting output. Due to the low quality of Islamic religious college education is also low quality of graduates produced.

From this point of view, it is clear that the pattern of Islamic religious college education which emphasizes only the ability to understand and repeat existing knowledge and ignore the ability to develop themselves for new knowledge will ultimately make these college graduate become parties harmed in interaction with other parties. For that reason necessary interdisciplinary cooperation in every branch of science, not least the knowledge of religion.

Overall, based on the condition of the field that there is low quality of Islamic colleges, because of the problems inherent in the development of lecturers and administrative personnel can be identified as follows:

\section{Individual Problems}

The problematic of educators and education personnel in Islamic colleges today is very complicated, blurred portrait of education Indonesia can not only to examine one component of educational institutions, but must be studied in full, including the problems of educators and education personnel because this is a the holistic part, can not be separated from the others. But the author will only focus on the problems of educators and education personnel to get a fairly complete discussion. Educational institutions will run with dynamics, success and problems encountered.

Lecturers are occupied by people who do not meet the requirements and qualifications as lecturers and not the competence (expertise). However, this is not a single fault individually, but the system contributes greatly to passing it. Such problems of course will be very disturbing the continuity of the course of education in a college, the learning process is not regulated systematically and directed, unable to use various methods in accordance with the circumstances of students, unable to carry out the evaluation of learning, so can not know the success rate in the learning process has been run. Worse, lecturers who do not meet the minimum educational qualification requirements still have a role in the learning process at colleges.

Therefore, the issue of minimum educational qualifications in accordance with their expertise should be the center of attention of the leadership as a hard effort in improving the quality of colleges. This is done so that the process of educating the quality of colleges continues to run and 
in accordance with educational goals that have been set previously. Therefore, awareness of this is not the responsibility of the head of a college, but lecturers must also be aware of the importance of improving the quality of education through the improvement of academic qualifications of educators to exceed the minimum academic qualifications of educators who have been regulated by the government.

In addition to the above problems, the relevance of lecturer-faced subjects with their majors need to be evaluated, since not least occur in the field, lecturers teach subjects that are not in accordance with the competence/expertise, such as majoring in Islamic religious education teaching philosophy of religion, research, and so forth.

This kind of problem will become the source of the problem in hampering the improvement of the quality of an Islamic college in accordance with the purpose of education, so that the lecturer cannot properly it material, the students are confused in understanding the material because the lecturer is unable to master the material optimally. It is important to find the solution, that is to replace with the relevant lecturer between the competence with the subjects that learned, especially to find the relevant lecturer with the competency quite easy considering the post graduates (Magister) with various competencies are quite easy to find, it's just need toughness, sacrifice, persistence and seriousness of the leadership.

The right of lecturers who are still far from the expectation of compensation of lecturers need to be considered considering the compensation is far from suitable for motivating the lecturers in carrying out daily tasks, so that the lecturers are more concentrated in carrying out their responsibilities without diminishing the energy and the mind to support the family in another way or work in other ways, although it is very difficult to provide for all the living expenses of each family, but at least enough to help in living costs and more feasible.

\section{Work Achievement}

Another problem is performance that is still weak. The performance of lecturers is one of the problems of problems faced by college lecturers. Good performance will greatly affect the success in carrying out the tasks held by the lecturers, on the contrary if the lecturers do not have good performance can be sure will get obstacles and challenges in carrying out responsibilities. In addition, the performance of lecturers have a very close relationship with the behavior, if the lecturers have good behavior will affect the performance in carrying out responsibilities that have been given, because when the good performance will understand that the responsibility has been given will be accountable to the leadership of the college. 
Therefore, the improvement of the lecturer's performance is not necessarily the responsibility of the head of the college, but the lecturers must also be aware of the importance of good performance to improve the quality of education in accordance with the educational objectives agreed previously. Performance is gained by carrying out each responsibility not as a profession only-a source of income in living everyday life, but must be based on sincere intention to participate in the success of improving the quality of education expected by all stake holders that exist.

In addition, lecturers who have work performance also need to be considered and given awards, lecturers who run their functions and tasks in accordance with the demands and expectations of all circles, the award is either in the form of material or non-material in accordance with the ability of universities, it is intended to provide motivation for lecturers continue to strive to always excel in performing their respective duties. Nevertheless, it is not uncommon to find a college that lacks appreciation of the work performance of lecturers, so that the lecturers often perform their duties only, such as teaching the system combined, teaching is not in accordance with the target face to face in the classroom.

Administrative and Academic Management

What is still prominent in Islamic colleges is the existence of sects, groups, Islamic organizations, student organizations that each other still cannot accept each other. Arrogance between them is still often the case, which in the end often occur conflicts in the college that should not be appropriate. Besides that. Service is still bureaucratic and formal; as well as less to show the nature of excellent service and less friendly to students. Under these conditions, the occurrence of unprofessional academic management, raises subjectivity that can lead to decreased quality of a college.

In addition to the problems in the development of teaching staff and administrative staff mentioned above, there are problems affecting the quality of Islamic colleges, including; First, Weak scientific community, one of the main prerequisites for the development of scientific research in any society is the presence of a minimum number of scientists and experts capable of conducting continuous and directed scientific research.

Secondly, Inadequate scientific research budget, almost in all Islamic religious colleges, the budget for scientific development and scientific research is very small, and does not occupy a significant place of Islamic national budget. In contrast, public colleges take a substantial portion of the national budget as a whole. Thirdly, there is a lack of awareness among academics in Islamic religious colleges about the importance of scientific research. Therefore, it is not surprising that those in charge of development policy formulation are public colleges, who often lack interest in the significance of science and technology development and 
research. They prefer to bring expertise (expertise), scientists, equipment, books of science from abroad.

Fourthly, inadequate library facilities, documentation and information centers, it is undisputed that scientific research requires the provision of information constantly and completely. But the facilities of Islamic religious colleges in this respect are very limited; this is one of the major weaknesses that hinders scientific development and research. The number of science books (physics and nature) available is very little. Most researchers in Islamic religious colleges have no access to scientific journals, and therefore have no material to follow scientific developments in their respective fields.

Fifth, Isolation of scientists, other situations that hinder the development of science and even the scientific capability to fade in the Islamic religious college is the isolation of scientists from the development of science globally. They hardly ever or rarely interact with scientists at advanced public colleges. In fact, every scientist in order to develop his knowledge needs to participate in discussions, seminars, and symposiums at the local, regional and international levels. He also needs to establish contacts and personal relationships with scientists and researchers at advanced public universities. It is also crucial for colleges and research institutes in Islamic religious colleges to collaborate with their colleagues in advanced public colleges, so that expert and expert exchange can be made. But financial difficulties are often the main obstacle to doing all this.

Sixth, Bureaucracy, restriction and lack of incentives. Science will obviously be more developed and useful when handled in an atmosphere that is free, or with minimal restrictions. The overly restrictive bureaucratic webs will only kill the creativity and research institutes in Islamic religious colleges that often can not move much because of boring bureaucracy and restrictions. The result is that routine is not creativity. In addition scientists in Islamic religious colleges do not get adequate financial and moral incentives.

From the above problems faced by the Islamic higher education world in the effort to develop science and technology, requires serious and effective governmental steps and policies, which is the Ministry of Religious Affairs. If the Government of Indonesia, for example, is serious and supported by stakeholders extensively in the development of science and technology, it can be understood that it will print ready-made output. If not, the "reconstruction of Islamic civilization" in the present and future lives only slogans and slogans (Azra, 2008, p. 72).

Under these conditions, the problems of human resources in Islamic religious colleges become increasingly complex, so it is indicated by the number of graduates of Islamic higher education who are not absorbed in the world of work. Moreover, plus many factors including; the 
increasingly volatile population, the growth of the workforce is greater than the availability of employment, the incompatibility of human resource competencies with the job market, the distribu- tion of information about the slow or unequal job market, the high unemployment rate.

\section{Conclusions}

In reality, in general it can be said that scientific mental attitude has not been formed in Islamic religious colleges, both among lecturers, especially among students. The atmosphere on campus until now can be said not yet achieved the scientific academic qualified. There is an atmosphere of routine academic community that organizes the educational process from day to day.

The low quality of Islamic religious colleges can be seen from three components, namely First, Islamic Religious College lecturers seem to be limited to performing teaching tasks and assessing student work. Secondly, students are less likely to have quality achievement targets and many students believe that diplomas are life provisions. Third, administrative personnel, Islamic religious colleges still show bureaucratic, rigid and formal conditions; as well as less to show the nature of excellent service and less friendly to students. The number of these conditions in the field, that the quality of Islamic religious college as a potential resource is still far from expectations.

The format that needs to be met first in achieving the quality of Islamic colleges is a broader concept of science in the view of Islam, accompanied by the freedom of the college in the field of study that must be taught; Islamic religious colleges should be research-oriented. In addition, it is necessary to have an academic community that has a soul of devotion, discipline, breadth of view, and critical understanding; selection of students required a more rigorous selection that will enter the Islamic religious college; as well as academic traditions. With this format, as an effort to realize the Islamic colleges as a vehicle that is expected to develop science and contribute to improvements in this era. Thus, Islamic religious colleges are not only trying to produce good graduates, but also qualified, skilled and ready to work.

\section{REFERENCES}

Arifa, Laily Nur. (2017). Perubahan STAIN/IAIN Menjadi UIN Sebagai Bentuk Pengembangan Pendidikan Tinggi Islam (Contoh Kasus 
Perubahan STAIN menjadi UIN Malang Perspektif Manajemen Perubahan Kurt Lewin). Jurnal Vicratina, Vol o1, No 2 (2017).

Azra, Azyumardi. (2000). Kuliah Perdana Program Studi Pendidikan Islam di PPs IAIN Sunan Kalijaga Yogyakarta, pada tanggal 28 Agustus 2000.

. (2005). "Model Perubahan IAIN Alauddin Menjadi UIN; Sebuah Tawaran Berdasarkan Pengalaman UIN Jakarta". in Hadi D. Mapuna dkk. (Ed.), Dulu IAIN Kini UIN Alauddin. Makassar: Alauddin Press.

--_endikan Islam: Akselerasi Perkembangan dan Tantangan Perubahan”. In Kusmana dan JM. Muslim, (Ed). Paradigma Baru Pendidikan: Restropeksi dan Proyeksi Modernisasi Pendidikan Islam di Indonesia. Jakarta: IAIN Indonesia Social Equity Priject (IISEP).

Fitri, Agus Zainal. (2013). Masa Depan Pergruan Tinggi Islam. Jurnal Epistemé, Vol. 8, No. 2, December 2013.

Hidayat, Komaruddin. (2000). Sambutan pada Acara Pertemuan Pimpinan Pascasarjana PTAIS se Indonesia di Hotel Setiabudi Jakarta, pada tanggal 16 Agustus 2000.

Madnasir. (2016). Integrasi Keilmuan IAIN Raden Intan Menuju UIN. Makalah Disampaikan pada Semiloka penulisan disertasi di gedung Pusdiklat Depag, Ciputat Jakarta.

Soedijarto. (2008). Landasan dan Arah Pendidikan Nasional Kita. Jakarta: PT. Kompas Media Nusantara.

Wahyudi, Kacung. (2016). Problematika Pendidik dan Tenaga Kependidikan di Perguruan Tinggi Islam. Jurnal Kariman, Volume 04, No. 01, Tahun 2016.

Widodo, Heri. (2015). Potret Pendidikan di Indonesia dan Kesiapannya Dalam Menghadapi Masyarakat Ekonomi Asia (MEA). Jurnal Cendekia, Vol. 13 No. 2, Juli - Desember 2015. 